\title{
Mística em C. S. Lewis: Experiência e literatura
}

\author{
Marcio Simão de Vasconcellos
}

\section{Resumo}

O objetivo deste texto é refletir sobre mística cristã a partir dos textos biográficos e ficcionais de C. S. Lewis, escritor irlandês, considerado um dos maiores pensadores cristãos do século XX. Trata-se, portanto, de um trabalho interdisciplinar que busca relacionar teologia mística cristã e literatura, em especial a literatura fantástica e de ficção deste autor.

Palavras-chave: Mística Cristã, C. S. Lewis, Literatura Infanto-juvenil.

\section{Abstract}

The objective of this paper is to reflect on Christian mystical from the texts of biographical and fictional C. S. Lewis, Irish writer, considered one of the greatest Christian thinkers of the twentieth century. It is, therefore, an interdisciplinary work that seeks to correlate Christian mystical theology and literature, especially fantasy literature and fiction by this author.

Keywords: Christian mystical, C. S. Lewis, literature for children and young people 


\section{Introdução}

A proposta desta pesquisa é pensar em mística cristã a partir da experiência pessoal e literária de C. S. Lewis, escritor irlandês, considerado um dos maiores pensadores cristãos do século XX. A obra de Lewis abarca diversos gêneros literários, incluindo textos teológicos, filosóficos, ensaios de crítica literária, poemas e de fantasia e ficção científica. Também foi professor de Literatura Medieval e Renascentista na Universidade de Oxford e em Cambridge. Sua produção literária é abundante e milhões de seus textos são vendidos a cada ano. Uma rápida pesquisa na Internet revela a quase inesgotável quantidade de sites destinados a C. S. Lewis ou à análise de suas obras.

Em que pese todas essas informações, há uma faceta de C. S. Lewis que ainda é pouco explorada em análises sobre este autor: sua dimensão mística. Esta dimensão surge tanto em seus escritos autobiográficos como nos seus textos de ficção que revelam sua compreensão sobre este tema. Na verdade, podemos afirmar que toda a vida de Lewis e praticamente toda sua produção literária (incluindo-se os textos de fantasia) trazem esse traço de uma experiência mística como elemento estruturador de seu pensamento.

Relacionar literatura e mística cristã sugere uma conscientização de que o "caminho místico de vida é experimentável em diversos contextos e situações" e por diferentes meios. Nesse sentido, também o é por meio da literatura. Aliás, a relação entre teologia cristã e literatura tem sido objeto de estudo de forma mais sistematizada nas últimas décadas, o que tem proporcionado - talvez, especialmente aos teólogos - uma abertura frutífera a um diálogo interdisciplinar capaz de levar à percepção de que o discurso teológico, por lidar com o humano, não pode se esgotar em racionalidades hermeticamente fechadas. Antes, existem outras dimensões essenciais para o ser que busca se compreender e dar sentido à sua existência. E uma dessas dimensões é o imaginário, "aquele de toda uma tradição onde ele se enraíza, feita de mitos, de contos e de lendas"2 e "do qual nos servimos desde nossa infância e que continuamos a edificar na fonte de nosso ser (...) todo esse imaginário vai infinitamente mais longe, como 'poder que agrega', que nossa razão"3

\footnotetext{
${ }^{1}$ SCHILLEBEECKX, Edward, História humana: revelação de Deus, São Paulo: Paulus, 1994, p. 101.

${ }^{2}$ GESCHÉ, Adolpho. O sentido, São Paulo: Paulinas, 2005, p. 139

${ }^{3}$ Idem
} 
A experiência mística cristã é capaz de resgatar essa dimensão integralmente humana da vivência com Deus. Justamente por ser uma experiência de "imediaticidade mediada", a mística cristã depende da linguagem metafórica. $\mathrm{O}$ encontro com o Mistério só pode ser expresso por meio de metáforas. A realidade última é inalcançável, a não ser através do caminho gerado pela linguagem simbólica e poética. Nosso acesso à realidade última sempre é mediado e toda palavra de Deus, para ter o que dizer a homens e mulheres, precisa encarnar e falar do ponto de vista humano. A Palavra se fez sangue, suor e lágrimas. Isto não é poesia em seu mais elevado grau?

Nesse sentido, a cultura humana é o espaço da linguagem religiosa, metafórica, simbólica, poética e literária. A cultura é, portanto, o lugar da experiência de Deus, da mística, e toda presença divina revelada aos homens e mulheres é mediada por estruturas humanas de percepção e de linguagem, embora, evidentemente, não se esgote nestas. Na verdade, a experiência mística sempre retrata o encontro de uma realidade (ou o ser encontrado por ela) mais surpreendente e encantadora que revela a inesgotabilidade da realidade somente naquilo que se percebe com os sentidos. Em outras palavras, o místico é aquele que sabe que "o mundo visível não esgota a realidade", e que experimenta uma "espécie de rompimento e ruptura do mundo inteiro; a vivência de algo inteiramente novo: luz ou fogo, ardor de amor, ou 'nada' ou um 'tu"' . É essa experiência que trataremos a seguir, evidenciando, posteriormente, sua presença nos textos de C. S. Lewis.

\section{Mística cristã}

A experiência mística cristã é essencial para se refletir sobre a revelação de Deus e sobre a experiência-encontro que se tem com Ele. Aliás, toda fé é mística, pois toda fé é pautada pela experiência do Mistério. A fé só se realiza na experiência; portanto, não é só ética nem só doutrina.

No cristianismo, ocorre a mística do encontro, e este encontro, como vimos, sempre é com uma dimensão incomensurável, impossível de ser abarcada em totalidade, inesgotável. Trata-se de um encontro com Algo que é "mais real do que a cadeira em que está sentado o místico, mais real do que

\footnotetext{
${ }^{4}$ SCHILLEBEECKX, Edward, História humana: revelação de Deus, p. 100

${ }^{5}$ VELASCO, Juan Martín, El fenómeno místico, São Paulo: Paulinas, 2001, p. 297.

${ }^{6}$ SCHILLEBEECKX, Edward, História humana: revelação de Deus, p. 101
} 
tudo o que este considera realidade" ". Encontro, aliás, que despedaça toda e qualquer imagem representativa de Deus, por mais importante e significativa que esta seja, pois é encontro com uma outra realidade que, "por sua natureza e essência é incomensurável e perante a qual recuo, tomado de estupefacção". ${ }^{8}$

Daí podemos afirmar que a experiência mística não pode ser produzida. $\mathrm{Na}$ verdade, a relação com Deus não pode ser reduzida a parâmetros cartesianamente mensuráveis, e nem as experiências místicas podem ser resumidas a proposições teológicas. Uma teologia mística não deve ser valorizada por seus conceitos doutrinais ou pela novidade de suas ideias - mesmo porque sua ênfase está na interiorização da revelação cristã e não em uma nova ou superior verdade revelada - mas antes, pelo caminho percorrido pelos místicos em suas experiências de encontros com Deus. Trata-se, portanto, de encontro com Deus na vida, pois "a própria vida é para os místicos, desde Agostinho, o drama do amor a Deus." "É apenas esta relação de amor entre o homem e Deus que pode humanizar a pessoa, tornando-a inteira, íntegra. Tal relação é a expressão da fé trinitária, pois é encontro com o Pai, com o Filho e com o Espírito Santo.

Essa experiência mística de Deus possui claras consequências para a vida. Sua presença não retira o místico do mundo, antes o leva a experimentar o mundo e seus anseios de forma mais profunda. Ao experimentar Deus, o místico abandona tudo e todos, mas não definitivamente. Antes, volta-se para tudo e todos, agora a partir de e com Deus, para então se reconciliar com a criação. Isso reflete um pensamento paulino muito claro, a saber, que "Deus estava em Cristo reconciliando consigo mesmo o mundo" e "nos confiou a palavra da reconciliação" (II Co 5.19). Toda a criação é, em Cristo, reconciliada; portanto, não pode haver espaços para dualismos, mesmo em nome da experiência mística. A partir disso, pode-se chegar a uma conclusão: a espiritualidade cristã e mística não é vivenciada fora do mundo, antes é encarnacional, e isto considerado até a última consequência. Somos mais espirituais à medida que somos mais humanos, vinculados ao próximo; "a verdadeira eternidade vive no plano do relacionamento pessoal" ". Por isso, a dimensão social-religiosa e profética não pode ser sacrificada em prol da experiência da unidade mística, pois esta, sem a ética revelada na prática do bem, é exercício inútil cuja única e exclusiva utilidade volta-se para o interior do próprio ser em

\footnotetext{
${ }^{7}$ SCHILLEBEECKX, Edward, História humana: revelação de Deus, p. 102

${ }^{8}$ OTTO, Rudolf, O sagrado, Petrópolis: Vozes, 2010, p. 40-41

${ }^{9}$ MOLTMANN, Jürgen, O Espírito da vida: uma pneumatologia integral, Petrópolis: Vozes, 2010, p. 189

${ }^{10}$ MOLTMANN, Jürgen, O Espírito da vida: uma pneumatologia integral, p. 30
} 
busca de bem-estar físico-psíquico. E, neste sentido, pode ser deturpada. Isso é ainda mais evidente na fé cristã, pois, de acordo com Jesus, esta fé, iluminada pela meditação mística, só tem sentido e valor se intimamente associada com a prática, isto é, a ação concreta em favor de alguém. Amor a Deus que se fecha em si mesmo, sem se abrir ao próximo e às suas necessidades concretas, não pode ser verdadeiro, ainda que advogue uma intensidade mística experiencial.

A fé oriunda do Reino de Deus não é abstrata, mas concreta e evidente no cotidiano: dar alimento a quem tem fome, água a quem tem sede, vestir os nus, visitar os presos, e acolher ao próximo, amando-o como a si mesmo ${ }^{11}$. Em Jesus, a unidade mística com o Abbá se dá tanto em sua espiritualidade, evidenciada em constantes e frequentes orações solitárias e em grupo com seus discípulos ${ }^{12}$, bem como em sua vocação profética de denúncia da injustiça praticada, sobretudo, contra os pobres de seu tempo. Mística e ética, portanto, não podem ser divorciadas. Aliás, a ordem de Jesus aos seus discípulos e discípulas não é que tivessem visões ou que experimentassem fenômenos extraordinários, mas que amassem uns aos outros, pois só o amor valida o seguimento de Cristo ${ }^{13}$.

Por fim, a união mística (unio mystica) é encontro com Deus. Porém, este encontro não dissolve a individualidade daquele(a) que se encontra com Deus, mas fortalece-a em sua profundidade. Ao olhar para Deus, "o místico fica tão seduzido que tudo, até ele mesmo, passa a segundo plano"14, sendo considerado um nada. Contudo, justamente por isso, as forças do eu se fortalecem. Vale fazer um paralelo dessa informação com o texto bíblico que afirma: "quem acha a sua vida, perdê-la-á; quem, todavia, perde a vida por minha causa achá-la-á” (Mt 10.39).

\section{A mística cristã em C. S. Lewis: experiência e literatura}

Nosso objetivo, nesse ponto, é apresentar alguns episódios da vida de C. S. Lewis e trechos de algumas de suas obras de ficção que tenham relação com sua busca por Deus e com sua experiência mística. A vida de Lewis foi marcada pela busca constante da Alegria. Para Lewis, Alegria relaciona-se com a saudade pela transcendência, pelo Mistério que é Deus. É o anseio por

\footnotetext{
${ }^{11}$ Cf. Mateus 25.31-46

${ }^{12}$ Cf., por exemplo: Mt 14.23, 26.36; Mc 1.35, 6.46; Lc 6.12, 9.28

${ }^{13}$ Cf. João $13.34-35$

${ }^{14}$ SUDBRACK, Josef, Mística: a busca do sentido e a experiência do absoluto, São Paulo: Loyola, 2007, p. 28
} 
uma experiência arrebatadora e significativa, geradora de sentido para a vida e reveladora da incapacidade humana de esgotar a realidade. Como ele afirma, "toda a Alegria lembra algo. Nunca é uma posse, sempre um desejo por algo remoto no tempo ou no espaço, ou ainda "prestes a vir a ser""15. Trata-se, portanto, de um desejo que, embora não satisfeito, é desejável, muito além de qualquer outra satisfação. Aliás, qualquer pessoa que já vivenciou a Alegria vai querer novamente senti-la. ${ }^{16}$. A Alegria, em si mesma, era sinal para outra realidade, melhor, mais abrangente e real, para a qual ela despertava o desejo.

Em Lewis, este despertamento que produziu o desejo de busca pelo Mistério - ou, para usar suas palavras, encontrar e ser encontrado pelo "Outro Inimaginável ou Insustentável"17 - se deu por via da literatura, especialmente a literatura de fantasia ${ }^{18}$. Dentre as obras que lhe trouxeram, em maior ou menor grau, lampejos da Alegria, destaca-se Phantastes, de George MacDonald ${ }^{19}$, um conto de fadas que produziu um grande impacto na vida de Lewis. Ao encontrar-se com este livro, Lewis tinha apenas dezessete anos, e, conforme ele mesmo afirmou, Phantastes batizou sua imaginação ${ }^{20}$.

Phantastes, na verdade, pode ser considerado um relato de uma experiência mística. $\mathrm{O}$ protagonista da narrativa é Anodos ${ }^{21}$, um jovem que perdeu a mãe durante a infância, e que possuía um forte desejo de visitar o reino das fadas, sobre o qual lera num conto de fadas. De fato, Anodos chega a uma floresta encantada, onde recebe conselhos de uma linda mulher, o espírito de uma faia, que o alerta sobre os perigos do seu mundo e depois o beija num frescor de sinceridade que reanima seu coração. Essa experiência, num primeiro momento, o deixa extasiado e sem falas, mas logo a seguir, Anodos percebe

\footnotetext{
${ }^{15}$ LEWIS, C. S., Surpreendido pela alegria, São Paulo: Mundo Cristão, 1999, p. 84.

${ }^{16}$ Ibidem, p. 25

${ }^{17}$ LEWIS, C. S., Oração: cartas a Malcolm, São Paulo: Vida, 2009, p, 17

${ }^{18}$ Em sua auto-biografia, Lewis cita duas obras que geraram este anseio: os livros de Beatriz Potter, autora de uma famosa trilogia infanto-juvenil com animais falantes como protagonistas, que fez o jovem Lewis enamorar-se de uma estação, o Outono, como uma experiência quase religiosa, de contato com "algo bem diferente da vida comum, e mesmo do prazer comum; algo como hoje diriam, 'de outro mundo"' (LEWIS, C. S., Surpreendido pela alegria, p, 24); e aquele que se tornaria um de seus livros prediletos: o conto de fadas Phantastes, de George MacDonald, que será abordado com maiores detalhes no decorrer deste artigo.

${ }^{19} \mathrm{O}$ texto integral em inglês encontra-se disponível em: http://www.gutenberg.org/files/325/325-h/325-h.htm

${ }^{20}$ LEWIS, C. S., Surpreendido pela alegria, p. 186

${ }^{21}$ Vale perceber que Anodos significa literalmente "aquele que perdeu o caminho". Cf. DOWNING, David, C. S. Lewis: o mais relutante dos convertidos. São Paulo: Vida, 2006, p. 72
} 
estar em completa harmonia com o mundo da natureza, compreendendo perfeitamente a conversa das árvores e dos animais e descobrindo dentro de si uma alegria nunca antes sentida ${ }^{22}$. A experiência forneceu-lhe uma nova maneira de ver o mundo à sua volta. Na narrativa, Anodos enfrenta vários desafios em sua jornada, chegando à exaustão, ao desespero, e, por fim, à morte numa batalha contra um lobo gigante. Porém, ele percebe que a morte não representava o fim; antes, anunciava um novo tempo no qual as dores da vida haviam passado e o ar fresco das montanhas da terra do norte podia ser respirado. As suas dúvidas e seu sofrimento haviam dado lugar à esperança, expressa nas últimas linhas do conto: "Sei que o bem está chegando até mim - que o bem está sempre chegando; embora poucos possuam, o tempo todo, a simplicidade e a coragem para acreditar nele." ${ }^{23}$. De maneira inequívoca, Anodos teve uma experiência mística que lhe deu sentido para a vida e mesmo para a morte. Após sua jornada no reino das fadas, ele reencontra seu caminho, consciente de um "poder de calma resistência" 24 recém adquirido que lhe mantém esperançoso e em paz.

$\mathrm{O}$ encontro com Phantastes alterou profundamente o jovem Lewis. Posteriormente, ele reconheceu que a narrativa em Phantastes iniciou um processo de conversão à fé cristã que foi lento e gradual, mas já nos primeiros momentos após encontrar-se com a narrativa, Lewis vivenciou algo fundamentalmente importante: "uma espécie de consciência da 'iluminação' (...) algo de inteiramente novo" "25, que mudou o seu modo de vida e sua concepção de mundo. Num de seus estudos sobre gêneros literários, escrito posteriormente, Lewis tece comentários interessantes sobre os contos de fadas, vinculando-os a uma nova forma de ver e se relacionar com o mundo. Em suas palavras, o país das fadas desperta em quem o lê "um anseio por algo que ele não sabe o que é. Comove-o, perturba-o (enriquecendo toda a sua vida) com a vaga sensação de algo que está além de seu alcance, e, longe de tornar insípido ou vazio o mundo exterior, acrescenta-lhe uma nova dimensão de profundidade. ${ }^{26}$. Justamente por isso, a literatura fantástica pode tornar-se caminho para a mística, levando seus leitores e leitoras a um novo sentimento de encantamento pela criação. Assim, "o menino não despreza as florestas

\footnotetext{
${ }^{22}$ Ibidem, p. 72

${ }^{23}$ Cf DOWNING, David, C. S. Lewis: o mais relutante dos convertidos, p. 74

${ }^{24}$ No original: "power of calm endurance". Cf.: http://www.gutenberg.org/files/325/325-h/325-h. htm (p. 118).

${ }^{25}$ SCHILLEBEECKX, Edward, História humana: revelação de Deus, p. 100.

${ }^{26}$ LEWIS, C. S., Três maneiras de escrever para crianças. In: LEWIS, C. S., Crônicas de Nárnia: volume único. São Paulo: Martins Fontes, 2009, p. 747
} 
de verdade por ter lido sobre florestas encantadas: a leitura torna todas as florestas de verdade um pouco encantadas. ${ }^{27}$

Esse fato manteve-se presente na consciência de Lewis durante toda sua vida, levando-o a não abandonar o mundo em prol de qualquer experiência de arrebatamento místico. De fato, a espiritualidade de Lewis não o afastava das coisas do mundo cotidiano. Isso é demonstrado em diversas de suas obras, em especial, no livro Cartas a uma senhora americana, no qual Lewis escreveu inúmeras cartas tratando de questões espirituais, mas também de situações comuns, como animais de estimação, resultados de exames médicos, resenhas de livros diversos, dietas, temperaturas etc. ${ }^{28}$, de modo bem semelhante às cartas de Santa Teresa. Aliás, em Lewis, a própria Natureza era um convite para um encontro místico: os céus misteriosos e distantes, as planícies ensolaradas, os montes praticamente inacessíveis, tudo isso arrebatava seus sentidos e lhe transmitia lampejos da Alegria ${ }^{29}$.

Como ocorre em seus textos autobiográficos, o restante da literatura de C. S. Lewis está repleta de elementos constituintes da mística cristã. É o que veremos a seguir a partir da análise de quatro de suas obras ficcionais.

\subsection{Anatomia de uma dor: um luto em observação.}

Este livro foi escrito logo após a morte da esposa de Lewis, a escritora Joy Gresham, vítima de câncer, em julho de 1960. Suas páginas desnudam dramaticamente o interior de C. S. Lewis. Em passagens repletas de sofrimento e angústia, Lewis apresenta seus questionamentos profundos e honestos, incluindo os que repetem a pergunta da cruz - "Deus meu, por que me desamparaste?" - que pontuam uma experiência intensa de dor e luto que não é facilmente apaziguada com a mera apresentação de dogmas teológicos teóricos. Mais que um relato de seu sofrimento causado pela perda, o livro descortina uma crise de fé enfrentada por Lewis - sua noite escura da alma - que o leva a questionar, não a existência de Deus, mas sim o seu caráter. Nesse sentido, Lewis vivencia a mesma expe-

\footnotetext{
${ }^{27}$ Ibidem

${ }^{28}$ Cf., por exemplo: LEWIS, C. S., Cartas a uma senhora americana. São Paulo: Vida, 2006, p. 47-48, 60, 88, 106-107.

${ }^{29}$ Em relação à natureza, Lewis diz que a experiência de contato com ela deve ser vivenciada em total submissão, sem realizar comparações de qualquer tipo; somente assim ela pode ser desfrutada. Por isso, diz Lewis, "cale a boca; abra os olhos e os ouvidos. Assimile aquilo que está ali diante de você, e não dê importância àquilo que podia estar ali, ou àquilo que está em algum outro lugar.". LEWIS, C. S., Surpreendido pela alegria, p. 150
} 
riência de diversos místicos cristãos que passaram a servir a Deus somente pela lembrança da fé outrora viva e claramente presente.

Mas volte-se para Ele, quando estiver em grande necessidade, quando toda outra forma de amparo for inútil, e o que você encontrará? Uma porta fechada na sua cara, ao som do ferrolho sendo passado duas vezes do lado de dentro. Depois disso, silêncio. Bem que você poderia dar as costas e ir embora. Quanto mais espera, mais enfático o silêncio se torna. Não há luzes nas janelas. Talvez seja uma casa vazia. Será que, algum dia, chegou a ser habitada? (...) Não que eu esteja (suponho) correndo o risco de deixar de acreditar em Deus. O perigo real é o de vir a acreditar em coisas tão horríveis sobre Ele. A conclusão a que tenho horror de chegar não é "então, apesar de tudo, não existe Deus nenhum", mas “então, é assim que Deus é realmente. Não se iluda.”. ${ }^{30}$

Em outra de suas obras ficcionais, Cartas a Malcolm, Lewis afirma que enfrentar situações-limite como essa é característico do ser humano, e quanto maior for a experiência mística com Deus, maior será a sensação de ter sido abandonado. Para Lewis, essa realidade se cumpriu integralmente em Jesus durante sua Paixão:

São os santos, não as pessoas comuns, os que passam pela "noite escura". São os homens e os anjos, não os animais, os que se rebelam. (...) A condição de ser oculto de Deus talvez cause maior dor ao pressionar aqueles que, sob outro aspecto, encontram-se mais próximos dEle, e portanto Deus mesmo, feito homem, será entre todos os homens aquele a quem Deus relegará ao supremo abandono. ${ }^{31}$

\subsection{Oração: cartas a Malcolm. Reflexões sobre o diálogo íntimo entre homem e Deus.}

Talvez esta seja a obra de Lewis que mais claramente trata da espiritualidade e da mística cristã como ele as compreendia. Segundo Lewis, o encontro com Deus exige e provoca ao mesmo tempo toda nossa atenção, pois se trata de uma relação inteiramente distinta das vividas no cotidiano ou mesmo na liturgia do culto.

Estou de pleno acordo em que a relação entre Deus e o homem é de índole mais particular e íntima do que qualquer outra relação possível entre duas

\footnotetext{
${ }^{30}$ LEWIS, C. S., Anatomia de uma dor, São Paulo: Vida, 2006, p. 31-32

${ }^{31}$ LEWIS, C. S., Cartas a Malcolm, p. 59-60
} 
criaturas da mesma espécie. Sim, ao mesmo tempo, porém, há, de outro aspecto, maior distância entre os participantes. Estamos nos aproximando - bem, não diria que do "Totalmente Outro", porque suspeito que se trate de algo sem sentido, mas do Outro Inimaginável ou Insustentável. Temos de estar - às vezes tenho esperança de que assim seja - simultaneamente conscientes da proximidade que beira a intimidade e da distância infinita. ${ }^{32}$

Uma relação como essa só pode existir por causa da pura graça e misericórdia de Deus. Como diz Lewis, "é Deus quem nos concede essa condição. Porque é pelo Espírito Santo que clamamos 'Pai"”33. É o próprio Deus quem ora por nós, pois "se o Espírito Santo fala no homem, na oração, Deus fala a Deus" ${ }^{\text {"34. }}$.

Para Lewis, o encontro místico com Deus o conduz à vida cotidiana, e não o separa dela. $\mathrm{O}$ espaço de sua espiritualidade é o ordinário, presente no dia-a-dia. Longe de desprestigiar a relação com Deus, esse fato fornece a ela a profundidade encarnacional, existencial, de uma vida vivenciada em integridade diante do Mistério divino. Por isso, as orações de Lewis eram feitas aproveitando-se qualquer espaço físico disponível - do banco do trem ao banco de um parque - e não se circunscreviam ao espaço litúrgico dos templos religiosos, pois, afinal, "não há templo algum na nova Jerusalém" 35 .

\footnotetext{
${ }^{32}$ Ibidem, p. 17

${ }^{33}$ Ibidem, p. 27

${ }^{34}$ Ibidem, p. 89. No mesmo livro, Lewis propõe esse tema a partir da beleza poética de um poema de autor desconhecido:

Dizem-me, Senhor, que quando imagino

contigo conversar,

Uma única voz se ouve, é tudo sonho

Um de dois imitando o falar.

Às vezes, é isso, mas não

como pensam. Busco antes

em mim o que aguarda manifestação.

Mas, ai!, secaram-me as fontes.

Vendo-me vazio, ao papel de ouvintes renuncias

E sopras por meus lábios mudos,

Expressão diligente Tu dás

A mim desconhecidos pensamentos.

De modo que não precisas nem podes

responder; embora cheguemos a aparentar

dois falantes, só Um tu sempre és

e eu, não o sonhador, mas teu sonhar.

Cf. LEWIS, C. S., Cartas a Malcolm, p, 88-89

${ }^{35}$ Ibidem, p. 41
} 
Para Lewis, toda separação dualística da vida em departamentos seculares ou sagrados trazia prejuízos à vida de relação com Deus e com o próximo. ${ }^{36}$

Por fim, para Lewis a experiência mística não pode ser validada por eventos sobrenaturais que porventura a acompanhem. Antes, o único critério é o amor.

\begin{abstract}
A normalidade, a segurança e a utilidade da viagem mística não dependem de forma alguma do seu caráter místico - isto é, do fato de constituir uma partida - e sim dos motivos, das habilidades e da constância do viajante, e da graça de Deus. A verdadeira religião dá valor ao próprio misticismo; o misticismo não valida a religião em que ele por acaso ocorre. (...) As partidas são todas iguais; é a chegada à terra que coroa a viagem. O santo, por ser santo, prova que seu misticismo (se ele for místico; nem todos são) o conduziu a bom termo. $\mathrm{O}$ fato de que praticou o misticismo não comprova de forma alguma sua santidade. ${ }^{37}$
\end{abstract}

E assim, conclui Lewis, o vislumbre de Deus na experiência mística é resultado não da busca pela experiência em si mesma, mas sim pelo desejo sincero de servir e amar a Deus. Quando embarcou na viagem mística, diz Lewis, o santo o fez "movido por um amor humilde e desinteressado." ${ }^{38}$. Ou ainda, e agora nas palavras de Santa Teresa: "Talvez digais: se assim for, como alcançaremos essas graças se não as procuramos? Respondo-vos que não há melhor maneira do que a que vos disse: não procurá-las." ${ }^{39}$. Tudo isso porque a experiência mística é graça de Deus e "por mais meditação que tenhamos e por mais que nos preocupemos e derramemos lágrimas, não é por aquedutos que essa água é conduzida. Ela só é concedida a quem Deus quer e, na maioria das vezes, isso ocorre quando a alma mais está despreocupada." ${ }^{40}$.

\title{
2.3. Cartas de um diabo a seu aprendiz.
}

Vimos que não há unidade mística à custa da individualidade do místico que a experimenta. Antes, como disse Teilhard de Chardin, "a unidade do amor não dissolve a independência dos amantes, mas oferece a cada um dos

\footnotetext{
${ }^{36}$ Ibidem, p. 42

${ }^{37}$ Ibidem, p. 85

${ }^{38}$ Ibidem, p. 86

${ }^{39}$ Santa Teresa de Jesus, Obras completas, São Paulo: Loyola, 1995, p. 479

${ }^{40}$ Ibidem, p. 479
} 
parceiros uma segurança mais profunda em si mesmo"41. A unidade trina de Deus, vivenciada em amor mútuo, é o que proporciona esta multiplicidade de "eus" no mundo criado. Esta unidade do amor não elimina a individualidade dos seres humanos que a vivenciam; antes, ela "aprofunda a peculiaridade dos parceiros" ${ }^{\prime 4}$.

Esse é um tema abordado num dos livros mais populares de C. S. Lewis: Cartas de um diabo a seu aprendiz. Mesclando ironia e sagacidade profunda, Lewis descreve as cartas de um secretário infernal, chamado Fitafuso, direcionadas a um subalterno, um tentador aprendiz, informando-o sobre a arte de conquistar almas humanas. Em uma de suas cartas, trata-se deste tipo de unidade de relacionamento entre Deus (tratado no livro como o "Inimigo") e o ser humano.

O Inimigo também quer que os homens se afastem de si mesmos, mas de modo diferente. Lembre-se sempre que Ele realmente gosta desses vermezinhos, e que dá um valor absurdo para a individualidade de cada um deles. Quando Ele fala sobre o fato de eles perderem a si mesmos, Ele apenas se refere ao abandono da vontade própria; uma vez alcançado esse abandono, Ele lhes devolve toda a sua personalidade e gaba-se (desconfio que o faça sinceramente) do fato de que, quando eles pertencerem totalmente a Ele, serão mais eles mesmos do que nunca. ${ }^{43}$

Neste livro, Lewis também trata do sentir-se abandonado por Deus - a noite escura da alma - mas o faz a partir de uma perspectiva infernal e como consequência direta do tornar-se a imagem de Deus no mundo. Na argumentação proposta por Fitafuso, Deus "abandona" seus servos mais santos para transformá-los naquilo que Ele quer que eles sejam. A não percepção de Deus, portanto, tem também um objetivo didático: gerar em seus filhos e filhas a capacidade de andar com as próprias pernas - andar por fé, poderíamos dizer - mesmo quando esta não passa de um balbuciar incompreensível, um gemido sem palavras, um grito na cruz. As preces oferecidas nesses momentos, segundo Lewis, são as que mais agradam a Deus. Como propõe Fitafuso no final da sua carta:

\footnotetext{
${ }^{41}$ SUDBRACK, Josef, Mística: a busca do sentido e a experiência do absoluto, p. 30

${ }^{42}$ Ibid., p. 33

${ }^{43}$ LEWIS, C. S., Cartas de um diabo a seu aprendiz, São Paulo: Martins Fontes, 2005, p. 64
} 


\begin{abstract}
Nunca a nossa causa corre tanto perigo como quando um humano que não deseja mais, mas ainda assim tenciona fazer a vontade do nosso Inimigo, perscruta um universo do qual Ele parece ter desaparecido sem deixar rastro, e pergunta por que foi abandonado, e ainda obedece. ${ }^{44}$
\end{abstract}

\title{
2.4. Trilogia Espacial
}

A Trilogia Espacial é composta pelos livros Além do planeta silencioso, Perelandra e Aquela força medonha. Nos três livros, existe uma atmosfera mística ao redor dos personagens, em especial ao redor de Ransom, o protagonista, que sofre intensa transformação ao longo da narrativa.

Em Além do Planeta Silencioso, o protagonista Ransom é levado cativo para outro mundo, Malacandra, cruzando o espaço por meio de uma nave espacial. Num primeiro momento, a visão do espaço o enche de terror ${ }^{45}$. Porém, a visão das estrelas infinitas, de constelações soberbas e cometas longínquos alterou essa percepção sobre o universo, levando-o a perceber o Espaço como um ambiente repleto de vida, um oceano do qual havia se originado os mundos. Ransom, maravilhado, concorda com os sábios que chamavam a vastidão do espaço de "os céus, os gloriosos céus" 46 .

Existe clara semelhança entre o que Ransom vivencia e a experiência mística de unidade com o cosmos. Nesse sentido, ambas as experiências percebem a unidade da criação no amor divino - aquilo que Ernesto Cardenal chama de "el ritmo del amor" 47 - que convida o ser humano a cantar e celebrar a Deus. Pois tudo suspira por Deus; Ele é o centro de todas as coisas, e somente nele descansará o universo. Há música e dança na criação e todos os seres participam também de um mesmo ritmo cósmico; todos em um mesmo ritmo, todos num canto entoado por todo o $\operatorname{cosmos}^{48}$.

Esta descrição mística é vivenciada por Ransom, no final de Perelandra. Na narrativa, o Rei e a Rainha daquele mundo recebem a criação como sua

\footnotetext{
${ }^{44}$ LEWIS, C. S., Cartas de um diabo a seu aprendiz, p. 40

45 "[Ransom] havia lido H G Wells e outros escritores. Para ele, o universo era povoado de horrores que ultrapassavam os da antiga mitologia. Achava muito provável que os habitantes deste mundo estranho fossem terríveis criaturas que se assemelhassem a insetos, vermes ou crustáceos, possuíssem antenas, asas, tentáculos e que unissem uma inteligência super-humana a uma crueldade insaciável." (LEWIS, C. S., Além do planeta silencioso, Rio de Janeiro: Edições GRD, 1958, p. 43-44).

${ }^{46}$ LEWIS, C. S., Além do planeta silencioso, p. 40

${ }^{47}$ CARDENAL, Ernesto, Vida en el amor, Buenos Aires: Carlos Lohlé, 1972, p. 24

${ }^{48}$ Cf. CARDENAL, Ernesto, Vida en el amor, p. 187
} 
herança. Neste momento, Ransom questiona sobre as últimas coisas, isto é, a destruição de seu mundo, a Terra. Mas para o Oyarsa, que dialoga com ele, isto não representa o fim, mas um novo começo onde todos seriam convidados a participar da Grande Dança, que "já começou antes de todos os tempos", de modo que "nunca existiu um momento em que não nos regozijássemos diante de Seus rosto, como fazemos agora" 49 .

No texto que se segue, Deus é o centro de sua criação, e todas as frases terminam com seu louvor: "Bendito seja Ele!". Tudo está interligado pelo amor de Deus, pois "Ele habita (todo Ele) dentro da semente da menor florzinha, e não Se sente apertado; e o Céu Profundo está contido nAquele que esta semente contém, e não o distende. Bendito seja Ele!" ${ }^{50}$. Assim, na perspectiva do livro, todos os eventos relacionados à história humana glorificam ao Criador, e toda criatura que se liga a Ele permanece no centro de tudo, não por causa de si mesmo, mas por causa Dele que é o centro do cosmos.

Tudo o que em si mesmo não é a Grande Dança foi criado para que Ele descesse e participasse dela. No mundo caído, Ele preparou para Si mesmo um corpo, e Se fez pó, e tornou-o glorioso para sempre. Isto é o alvo supremo, a causa final de toda criação. E o pecado por meio do qual ela ocorreu é chamado de Feliz, e o mundo onde esta realidade foi executada é o centro dos mundos. Bendito seja Ele! (...) Todas as coisas foram criadas por ele. Ele é o centro. E como nós estamos com Ele, cada um de nós está nesse centro. (...) Cada coisa, desde um simples grão de pó ao mais forte eldil, é o objeto e a causa final de toda a criação; um espelho, no qual o raio de Seu brilho vem repousar e depois se reflete de volta para Ele. ${ }^{51}$

\section{Conclusão}

Esgotar um tema como esse - mística cristã - a partir das obras de C. S. Lewis não é tarefa possível a esta pesquisa. O que se propôs foi apenas apresentar uma chave de leitura - de tantas possíveis - para os textos de Lewis que os vinculassem, ainda de forma mais clara, à teologia cristã.

Lewis não foi um teólogo - sua formação era em Literatura e Filosofia - mas certamente foi um cristão piedoso, para quem as experiências místicas, ainda que não fossem o alvo de sua vida, não foram algo estranho. Antes,

\footnotetext{
${ }^{49}$ LEWIS, C. S., Perelandra, Minas Gerais: Betânia, 1978, p. 274

${ }^{50}$ Ibidem, p. 274-275

${ }^{51}$ Ibidem, p. 275-277
} 
muitas de suas obras podem ser melhor compreendidas tendo esta chave hermenêutica como meio de acesso ao seu pensamento. Podemos afirmar, portanto, que em Lewis existe uma clara dimensão mística, que fornece profundidade e direcionamento às suas obras literárias.

David Downing relata um acontecimento na vida de C. S. Lewis registrado pelo seu secretário, Walter Hooper, que vale ser citado neste momento. Após ter sofrido um ataque cardíaco e ter sido internado numa casa de saúde em Oxford, Lewis acordou de um cochilo e pediu a Hooper um copo d'água.

Quando este foi até a garrafa ao lado da cama, Lewis de repente recostou-se e fitou o olhar atento no lado oposto do quarto. Hooper não viu nada, mas percebeu que Jack devia ter visto algo ou alguém "muito grande e belo" ali perto, pois havia em seu rosto uma expressão extática diferente de tudo o que Hooper jamais vira. Jack continuou fitando e repetiu várias vezes para si mesmo: "Ah, eu nunca imaginei, eu nunca imaginei". A expressão de júbilo permanecia em seu semblante quando ele tornou a repousar a cabeça no travesseiro e adormeceu. Mais tarde, nada lembrava desse episódio, mas dizia que até refletir sobre isso com Hooper lhe proporcionava um "descanso do espírito". 52

Talvez, no fim de sua vida, Lewis também tenha sido encontrado pela dama de Phantastes, a mesma que transmitiu a Anodos um beijo reconfortante. E, como ocorre com toda experiência mística, lhe foi impossível expressar em palavras exatas sua experiência. Restou-lhe a certeza de que o bem está sempre chegando.

\section{Referências Bibliográficas}

CARDENAL, Ernesto. Vida en el amor. Buenos Aires: Carlos Lohlé, 1972.

DOWNING, David. C. S. Lewis: o mais relutante dos convertidos. São Paulo: Vida, 2006.

DURIEZ, Colin. Tolkien e C. S. Lewis: o dom da amizade. Rio de Janeiro: Nova Fronteira, 2006.

GESCHÉ, Adolphe. O sentido. São Paulo: Paulinas, 2005.

${ }^{52}$ DOWNING, David, C. S. Lewis: o mais relutante dos convertidos, p. 174 
GREGGERSEN, Gabriele. Antropologia Filosófica de C. S. Lewis. São Paulo: Mackenzie, 2001.

LEWIS, C. S.. Surpreendido pela alegria. $2^{\mathrm{a}}$ edição. São Paulo: Mundo Cristão, 1999.

. Oração: cartas a Malcolm. Reflexões sobre o diálogo íntimo entre homem e Deus. São Paulo: Vida, 2009.

. Cartas de um diabo a seu aprendiz. São Paulo: Martins Fontes, 2005.

. O grande abismo. São Paulo: Vida, 2006.

. A anatomia de uma dor: um luto em observação. São Paulo: Vida, 2006.

. Cartas a uma senhora americana. São Paulo: Vida, 2006.

. Além do planeta silencioso. Rio de Janeiro: Edições GRD, 1958.

. Perelandra. Minas Gerais: Betânia, 1978.

. Aquela força medonha. Portugal: Europa-América, 1991. Volume 1.

. Aquela força medonha. Portugal: Europa-América, 1991. Volume 2.

. Três maneiras de escrever para crianças. In: LEWIS, C. S., Crônicas de Nárnia: volume único. São Paulo: Martins Fontes, 2009.

MACDONALD, George. Phantastes: a faerie romance for men and women. Edited by Greville MacDonald.

MOLTMANN, Jürgen. O Espírito da vida: uma pneumatologia integral. Petrópolis: Vozes, 2010.

OTTO, Rudolf. O sagrado. Petrópolis: Vozes, 2010.

SANTA TERESA DE JESUS. Obras completas. São Paulo: Loyola, 1995.

SCHILLEBEECKX, Edward. História humana: revelação de Deus. São Paulo: Paulus, 1994.

SUDBRACK, Josef. Mística: a busca do sentido e a experiência do absoluto. São Paulo: Loyola, 2007.

TILLICH, Paul. Teologia da cultura. São Paulo: Fonte Editorial, 2009.

. Dinâmica da fé. $7^{\mathrm{a}}$ ed. São Leopoldo: Sinodal, 2002.

. Textos selecionados. São Paulo: Fonte Editorial, 2006. 
TODOROV, Tzvetan. Introdução à literatura fantástica. $4^{\mathrm{a}}$ ed. São Paulo: Perspectiva, 2010.

TOLKIEN, J. R. R.. Sobre histórias de fadas. São Paulo: Conrad do Brasil, 2006.

VELASCO, Juan Martín. A experiência cristã de Deus. São Paulo: Paulinas, 2001. . El fenómeno místico. Madri: Editorial Trolla, 1999.

YUNES, Eliana et al (org.). Teologias e literaturas. São Paulo: Fonte Editorial, 2011.

Marcio Simão de Vasconcellos Mestrando em Teologia Sistemático-Pastoral na PUC-RJ

Especialista em Ciências da Religião pela Faterj Professor de teologia na Unigranrio (Duque de Caxias) e no Instituto de Educação Teológica (IET) em Teresópolis. E-mail: marciosvasc@gmail.com

Recebido em: 27/09/12 Aprovado em: 27/10/12 